\title{
The Human Zoo: A Critique of Brett Bailey's Exhibit B
}

\author{
- Mercadies Brown, Ball State University
}

W ith Brett Bailey's modern re-creation of early nineteenth-century human zoos, many have engaged in public critiques of the colonial practice of putting humans on display. Exhibit B, Bailey's installation, is meant to spread awareness of the widely popular human zoos of the past. Audiences stand on both sides of Exhibit B-some protesting the "otherness" of hired actors and some praising the risks Bailey takes by creating such an exploitative performance. My essay investigates whether or not re-creating scenes of slavery does more harm than good. In order to spread awareness of early nineteenth and late twentieth-century human zoos, Bailey subjugates non-white actors to portray performances similar to those from these previous periods. Is there an effective way to recreate scenes of slavery and oppression? Does Exhibit $B$ provide a critique of racism and colonialism? Or, could Exhibit $B$ be another instance of racism?

In this paper, I am going to argue that Brett Bailey's Exhibit $B$ is a poor attempt to provide an artistic critique of nineteenth and twentieth-century colonialism and racism in the practice of the human zoo. I will do this by examining the history of the human zoo and recounting the story of the real-life Hottentot Venus. This will help us understand how the human zoo is historically tied up with colonialism and racism. I will then look at Bailey's own views surrounding Exhibit B and, lastly, I will provide an analysis of why Exhibit $B$ is not a proper representation of the history of American and European ethnological enlightenment. I will also discuss why Bailey's intentions cannot overcome the colonialism and racism that lingers around his modern re-creation of the human zoo.

If you think the human zoo is a thing of the past, you may want to reconsider. South African artist Brett Bailey has created a modern representation of the human zoo called Exhibit B. In his exhibit, actors portray nineteenth-century human zoos in scenes that have been historically re-created. In one such scene, titled "Civilizing the Natives: Herero prisoners cleaning Herero skulls for European museums," two African-American women hold human skulls and pieces of glass. The plaque next to this display explains the history of African women being forced to clean skulls that were meant to be sent to Germany for "pseudoscientific examination" in the late nineteenth and early twentieth century (Carvajal). In Bailey's rendition, the women are enclosed 


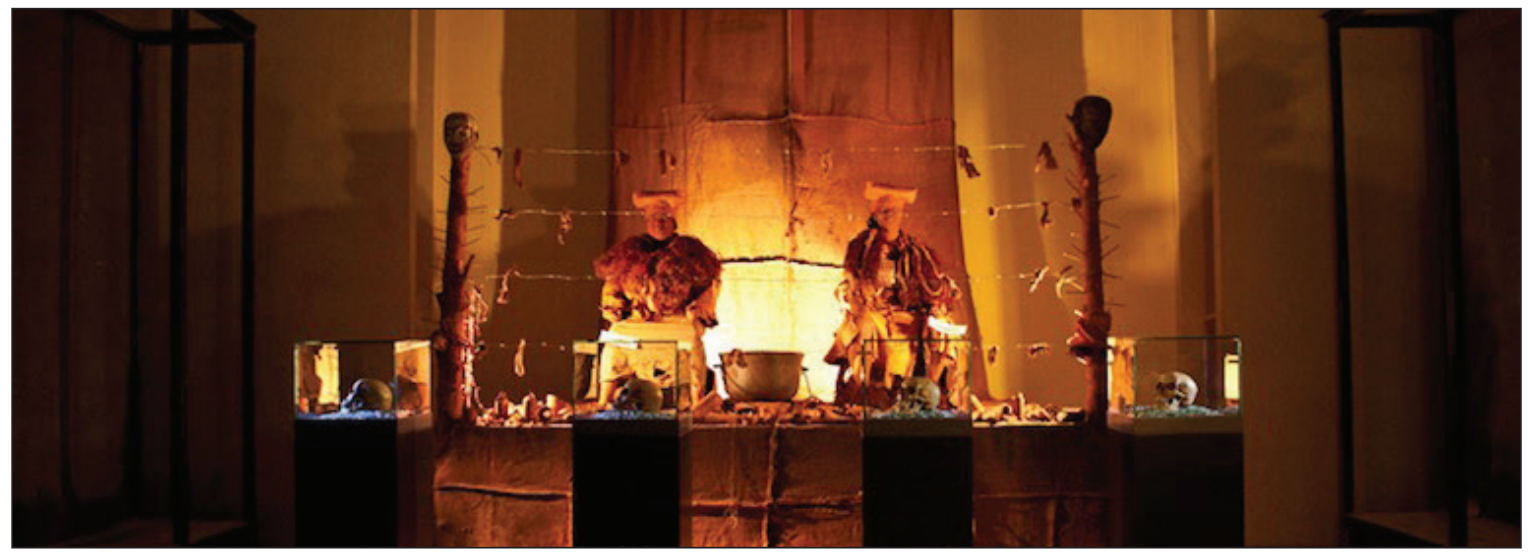

Civilizing the Natives: Herero prisoners cleaning Herero skulls for European museums (C Brett Bailey

in a small area, fenced off by barbed wire. A large cooking pot sits upon a stack of wood between the women. Hanging from the barbed wire are what look to be pieces of flesh. The entire display is placed behind four pedestals, and on these pedestals are four skulls enclosed in glass cases. A backlight causes the faces of the women to be lost in shadows - the darkness of the exhibit further dimming their already dark skin. Spotlights draw attention to the hands of the actresses, causing the audience to focus on the actions taking place, as described by the plaque.

Also featured in Exhibit B is "A Place in the Sun: quarters of an officer of the German Colonial Forces, Windhoek 1906." This scene involves a woman with an iron chain around her neck. In the eighteenth, nineteenth, and even early twentieth century, it was common practice for European colonists to chain up an African woman and allow her access to food in exchange for sexual services. This type of action sought to demean the women to little more than poorly treated house pets. As an African-American actress sits on a bed inside Bailey's "A Place in the Sun" exhibit, she stares into a mirror hung on the wall. With her back to the audience, the only sight of this woman's face is whatever glimpse of reflection you may catch in the mirror. Clothed in only a bed sheet, emphasis is placed on the chain collar around her neck. On the walls hang animal furs and heads, as well as framed photos of indigenous tribes. The woman is not given a name, but instead a

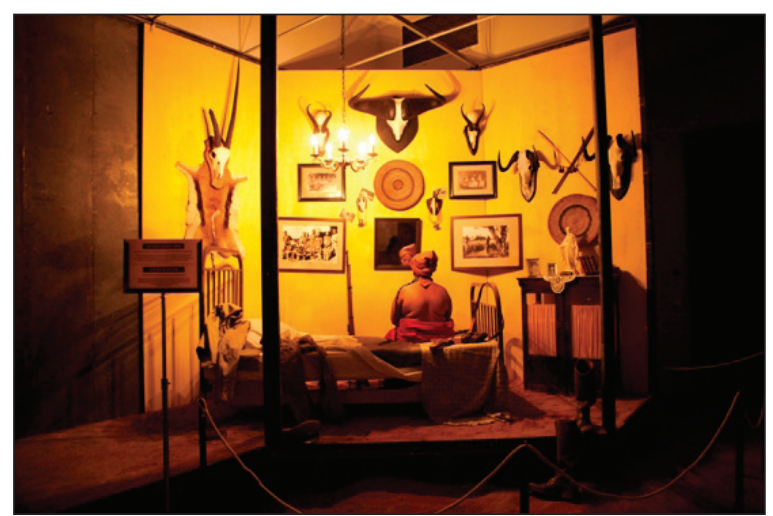

A Place in the Sun: quarters of an officer of the German Colonial Forces, Windhoek 1906 (c) Brett Bailey piece of paper scribbled with a series of numbers is attached to the sheet that she wears in lieu of a nametag. A man's clothing and belongings are scattered about the room. His pants lie across the bed and his boots are thrown about the floor. A rifle is propped against the bedpost should the woman get any ideas about escaping her chain collar.

The exhibit has caused such uproar that Change.org features a petition to have the London showing cancelled. Protestors did end up with a victory, as this particular London theatre, the Barbican, withdrew its showing of Exhibit B. Responding to the cancellation, Bailey wrote an article featured in The Guardian which included the following:

The intention of Exhibit $B$ was never hatred, fear, or prejudice. It is about love, respect, and outrage. Those who have caused Exhibit $B$ to be shut down brand the work as racist. They have challenged 
my right, as a white South African, to speak about racism the way I do. They accuse me of exploiting my performers. They insist that my critique of human zoos and the objectifying, dehumanizing colonial/racist gaze is nothing more than a recreation of those spectacles of humiliation and control. The vast majority of them have not attended the work ... I do not portray the world in the binaries of black and white, wrong and right, good and evil. I am an artist who works with colours and shades. (Bailey, "Yes, Exhibit B is Challenging")

With thirty-eight tour dates scheduled for the 2014 calendar year, Bailey's exhibit has been able to spread awareness regarding European and American history of "ethnological enlightenment" ("The Human Zoo" 3). The question remains, however, if awareness was spread in a manner deemed appropriate.

Before further examining Exhibit B, we first need to look at the long history of the human zoo in order to understand the importance of the racial ties that continue to be present in Bailey's modern re-creation. Zoos have been a large part of human history. Once entrepreneurs figured out that an audience would pay to see unique and exotic animals brought to nearby cities, zoos rapidly became popular. Lydia Kallipoliti recounts historical zoological events in her article, "Evolution of the Zoo: An Overview of Significant Zoological Developments Spanning from Biblical Times through to Contemporary Proposals." She describes the pre-modern zoos as such:

These aristocratic ménageries_-including the Tower of London and the Vincennes Ménageriewere founded and owned by said aristocrats whose primary intentions were not scientific or educational but rather illustrated their established power and wealth as it required both of those conditions to acquire exotic animals. By the late seventeenth century, ménageries had developed into places where wild animals were kept and trained for the purpose of exhibition. Animals were objectified-collected and displayed in a similar manner to the cabinet of curiosities of Renaissance Europe in which rulers and aristocrats would showcase their personal collections (3).

Kallipoliti's description of pre-modern zoos provides a basis upon which we are able to associate the first animal zoos. It is not until later, around the nineteenth century, that zookeepers begin displaying humans alongside animals. As Kallipoliti notes, the Age of Enlightenment largely influenced the changes to zoos and what became known as the "modern" zoos: "Thus the symbolic use of animals began to merge with notions of a well-ordered universe, leading to the collection of live specimens for study rather than amusement and ultimately to the development of the first scientifically established zoos of the modern world" (9). With this shift to science-focused zoos, it would not be long before zookeepers began expanding their search of "live specimens" to include humans.

In the late 1800's, cities such as Paris, Hamburg, Barcelona, and Milan were home to human zoos. Even some American cities, such as New York, hosted the human exhibits. M.B. David notes in the article “Deep Racism: The Forgotten History of Human Zoos," that some 200,000 to 300,000 people visited these zoos collectively. The human zoos consisted of public exhibits of mostly non-European people. These people were often considered different and unusual to what Europeans were used to seeing. As part of the exhibit, the humans on display would be placed inside a habitat. These constructed habitats often offered ideas of where these people might naturally exist.

Carl Hagenbeck, considered to be a German entrepreneur of human zoos, exhibited Nubian people in 1876. While working with a collaborator for the Nubian exhibit, Hagenbeck requested "wild beasts" be placed in the exhibit. Hagenbeck considered his exhibits of human beings to be "savages in a natural state" (Ames 27). Beginning in 1874, Hagenbeck critiqued and perfected zoo exhibits, for humans and animals alike. In one such show called "The Savages from the Land 
of Fire," Hagenbeck displayed a group of Kaweskars, people native to the Tierra del Fuego area of the South American Chilean Patagonia. Hagenbeck's expedition captured the Kaweskars and displayed them to an audience of half a million visitors in Paris alone ("Europe's 'Human Zoos'”). Human zoos had gained so much popularity that the 1889 World's Fair featured an exhibit with four hundred indigenous people (David).

By the early twentieth century, human zoos had sprung up across Germany. With big names like Hagenbeck, Germany helped human zoos, or "Peoples Show," to gain popularity throughout the Western world. A Congolese pygmy called Ota Benga was displayed in a primate exhibit at the Bronx Zoo in New York City from 1906 until 1910. A plaque outside Benga’s exhibit labeled him as, "The Missing Link" (David). A zoo in France continued to display an Ivory Coast Village as part of an African safari up through 1994, as well as a London zoo including an exhibit depicting the earliest Homo sapiens in 2005 (David). In a document titled The Human Zoo: Science's Dirty Secret, Channel Four Television Corporation investigates late nineteenth and early twentieth-century cultural practices regarding indigenous peoples. The document states, "Scientists were so fascinated by race that thousands of indigenous people from all over the world were put on display in human zoos in pseudo-scientific demonstrations of 'racial difference”" ("The Human Zoo" 3). Though the concept of a zoo began with animals, it quickly incorporated human specimens. Just as the animals had been captured from their homelands and objectified for visitors to gawk at, the same ended up happening to people.

Perhaps the most famous story involving the human zoo is that of Saartjie Baartman. Baartman's story describes the life of an indigenous woman captured for display in a human zoo. Baart-

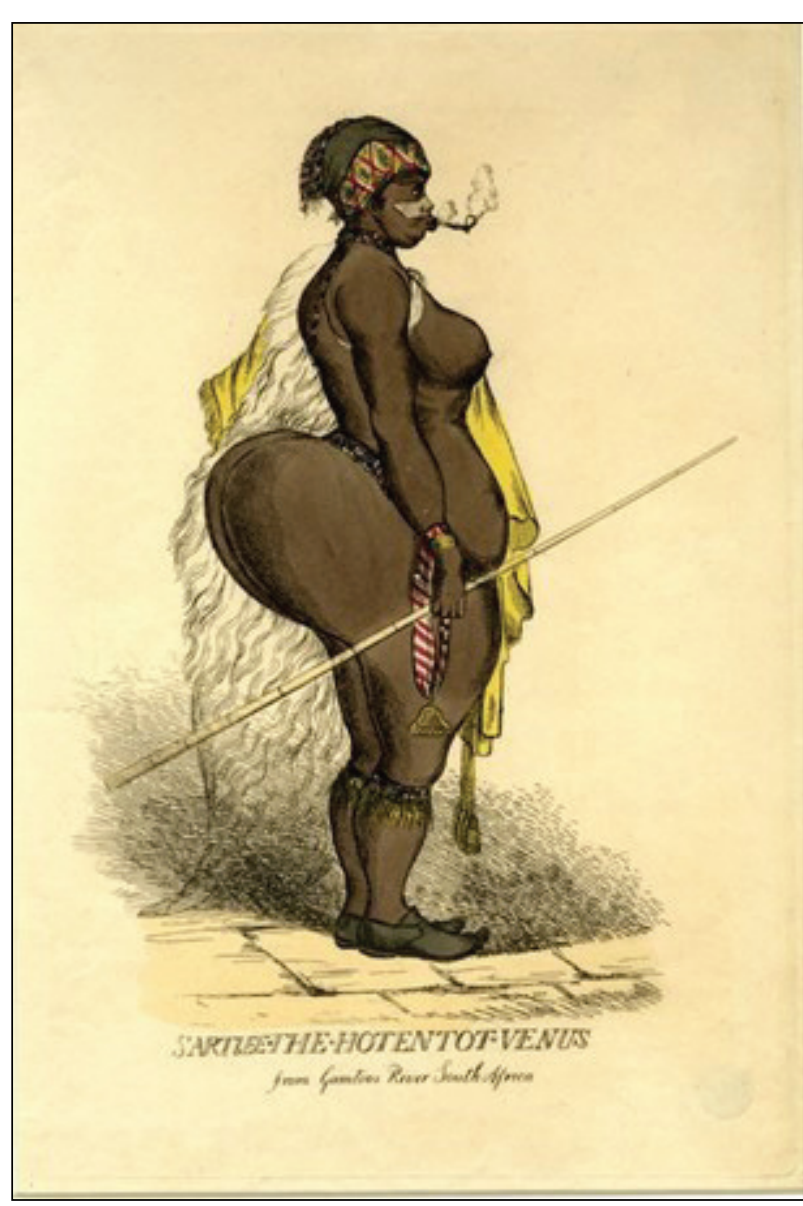

Portrait of Saartjie Baartman, naked (c) British Museum man was deceived by European explorers and kidnapped from her home. Like other performers, Baartman was taken because of her unusual appearance. Human zoos, and their audiences, thrived off of exotic specimens. If white Europeans had not seen something before, it was sure to be a hit at a freak show carnival. Baartman became known as "The Hottentot Venus," and from that point on, she wouldn't be known by any other name. Tortured and inspected, Baartman's story is one of few historical accounts of human zoo captivity that was ever recorded.

Born in the Eastern Cape of South Africa in 1789, Saartjie Baartman would be taken from her homeland and eventually brought to England to be displayed in a collection of human spectacles (Holmes). Baartman agreed to venture to London, reassured by an exotic animal dealer that she would gain fame and wealth. Human zoo exhibits often sent scouts to find recruits with aesthetic qualities "that either coin- 
cided with the European beauty ideal or offered unexpected novelty" (David). Baartman lived in Europe from 1810 until 1815. She was placed on stage in London amongst other members of the human freak show. Displayed for her genetic condition, steatopygia, Baartman had protuberant buttocks and elongated labia (David). Clifton Crais, history professor at Emory University, writes "for a little extra, you could poke her with your fingers or a stick" (Qtd. in Firth). In Searching for Sara Baartman, Susan Firth notes: "Since her death, the Hottentot Venus has appeared in the writings of William Makepeace Thackeray, Victor Hugo, Charles Darwin, Stephen Jay Gould, even Barack Obama's inaugural poet, Elizabeth Alexander. These days, activists and academics claim her as a symbol of Western exploitation and racism" (Firth). Baartman died in 1815 and continued to be displayed to the public (Davie). As recently as 1974, the remains of Baartman, along with her genitalia, were displayed in France's Musée de l'Homme, which translates to Museum of Man. Ridiculed and pestered for five and a half years of her life, Baartman continued to be taunted after death. In 1994, President Nelson Mandela formally requested that Baartman's remains be returned to Cape Town. Baartman was not returned to South Africa until 2002, 187 years after leaving for Europe (Davie).

Her story provides us with a glimpse into the life of a human zoo specimen. By understanding Baartman's account, we can better relate to what is going on in Exhibit B. Baartman's experience tells us that the nature of human zoos was one of cruelty, torture, and inhumanity. Her story helps me shape an analysis for Bailey's exhibit by giving me an inkling of an idea about how these zoos worked. For someone like Bailey to re-create an environment like this, it not only creates a controversial endorsement of racism, but it also negates and dishonors any humanity that Baartman, and others like her, had left. To take non-white volunteers and place them into a historical depiction to the liking of what Baartman suffered is to strip these people of their humanity and makes them pawns in a game of objectification.

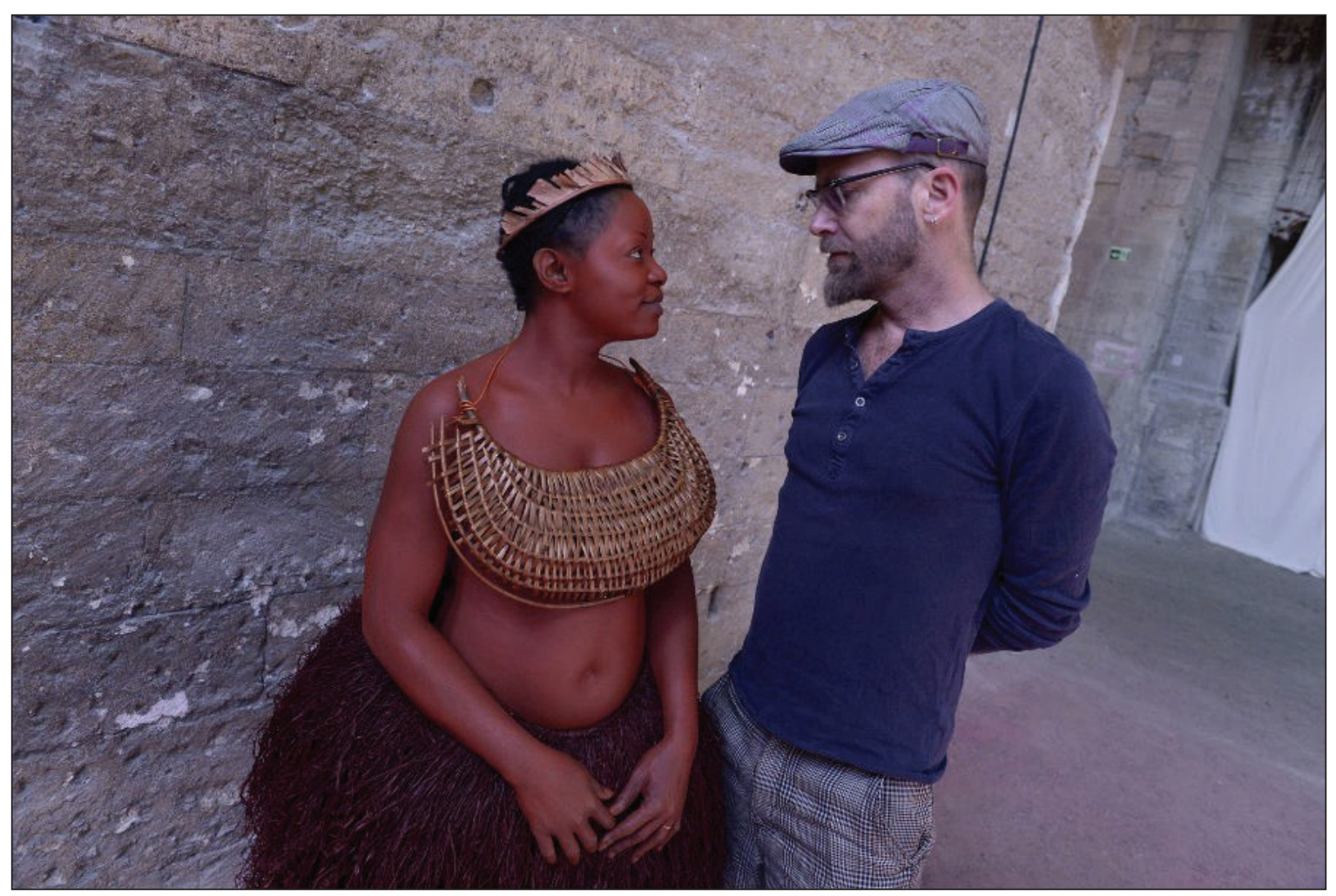

Brett Bailey with a performer from Exhibit B @ Pascal Gely 
As I was reading through the tour dates of Exhibit B, I began to look up the venues that would be hosting Bailey's show. I located web pages of four venues on the touring list. Of these four venues, two charged admission (Poitiers-TAP, Moscow-Museum of Modern Art) and two appeared to be free to the audience (Paris-Theatre Gerard Philipe de Saint-Denis, Edinburgh International Festival). Because we have been presented with venues that charge and venues that do not, we can address both sides of this matter and how it may complicate Bailey's installation. On one hand, we must consider what it means to have humans on display like animals and to charge an audience an admission fee to see these spectacles. While Bailey argues that he is attempting to make a point with his artistic abilities, we are left wondering how much compensation he could be making from admission fees, and further, whether or not his live displays are being paid justly, or at all, for their time. Is Exhibit $B$ able to send a message about the horrible acts of racism and colonialism committed in the nineteenth and twentieth centuries while still profiting from spectators, just as the original human zoo did? Knowing Baartman's history, are we able to comfortably allow Bailey to objectify actors-be it at their own will? We know that human zoos of the past charged an audience to view the humans on display. One may consider that Bailey has crossed a line by displaying his exhibit in a venue that charges admission. Can we then argue that admission-free venues showing Exhibit $B$ are more successful in spreading awareness about the human zoo? If an audience sees that show, and has not spent money on it, are they more likely to see the atrocities of these historical acts? Or perhaps, because they have not invested money, they may care less about what the exhibit is trying to show? These questions help determine the lack of critique that Exhibit $B$ provides.

Human zoos are not a modern-day practice because humans have realized the cruelty and objectification that takes place within these settings. Though Bailey promotes Exhibit $B$ as an artistic journey through ethnological enlightenment, this show does not totally eliminate the racism involved. Bailey's Exhibit $B$ does not properly critique historical racism and colonialism because he has not drawn a line thick enough between what happened in the past and what he is doing now. To an audience with little to no knowledge of European and American human zoos, Exhibit B simply looks like a racist white man decided to morph his superiority complex into a live display. Even for those who are fully aware of what happened regarding human zoos, Bailey's comparison comes too close to the real thing.

Though collections like Exhibit B provide the audience with informative scenes about slavery and racism, these pieces still objectify the actors performing within the art. By using actors to recreate nineteenth-century human zoos, Bailey is, in turn, exerting power over other humans. It also does not help matters that Bailey is not a man of color. To have a white man create exhibits of colonial slavery drudges up ideas of superiority that some would much rather leave in the past.

Equality has become more widespread in today's culture. We are much farther along as a species than we were in the times of the human zoo. Objectification is a sensitive subject and must be addressed in a sensitive and respectful manner. Exhibit $B$ transports the audience back to centuries when racial intolerance was at large. Rather than painting a scene from a human zoo exhibit, or sculpting a statue of The Hottentot Venus, Bailey uses real, live people in an attempt to show his stance on racism and colonialism. Where that failed, however, is in his execution. Bailey's exhibit allows current spectators to place themselves in an actual human zoo. Exhibit B is no different than Hagenbeck's zoo. By understanding the cruel history of Saartjie Baartman, Hagenbeck's Nubian captives, Ota Benga, and other humans put on display, we gain 
perspective about this modern recreation. Visitors obviously know that these people are not being held against their will, but the visitors are still doing the same thing that was done hundreds of years ago: observing humans in an unnatural state.

Since he began touring Exhibit B in 2013, Bailey's work has engaged many people in public critiques of historical human zoos. By examining the history of the human zoo, we can better understand the racial ties that Bailey's show carries along. We are able to recognize the underlying trend of superiority and objectification that allowed human zoos to thrive in the past. The story of Saartjie Baartman gives us evidence that the practice of human zoos involved people being captured and displayed like wild animals. By creating Exhibit B, Bailey has tried to spread awareness about the pseudo-scientific enlightenment that took place in the nineteenth and twentieth centuries, but his exhibit does not totally eliminate racism. It seems that no matter how carefully recreations are handled, people still end up being objectified.

Ultimately, there are costs to recreating scenes of slavery. Our world already has a hard time honoring equality to all humans. No matter how good artistic intentions may be, any performance that objectifies other human beings is not worth the cost. Though we constantly strive to gain understanding of past events, it could be possible that our continuous efforts are not bringing us any closer. It does not matter how hard we try; we will never know what it is like to be in another person's situation. Bailey, and numerous others, attempt to bring understanding to viewers, but what is lost in the process? I believe it is time to approach historical slavery and colonialism in a new way. That could mean many things. It may involve us reevaluating how we think about these situations, or it could possibly encourage us to change how we teach future generations about these atrocities. Whatever the solution is, we have not yet reached it. 


\section{Works Cited}

Ames, Eric. Carl Hagenbeck's Empire of Entertainments. Seattle: U of Washington, 2009. Print.

Bailey, Brett. "Yes, Exhibit B Is Challenging - but I Never Sought to Alienate or Offend." The Guardian. Guardian News and Media Limited, 24 Sept. 2014. Web. 13 Jan. 2015.

---. "Exhibit A B and C.” Third World Bunfight. Third World Bunfight, 26 Sept. 2014. Web. 7 Jan. 2015.

Carvajal, Doreen. “On Display, and on a Hot Seat: 'Exhibit B,' a Work About Human Zoos, Stirs Protests.” The New York Times. The New York Times Company, 25 Nov. 2014. Web. 13 Jan. 2015.

David, M.B. “Deep Racism: The Forgotten History of Human Zoos.” Popular Resistance. PopularResistance.Org, 18 Feb. 2014. Web. 30 Dec. 2014.

Davie, Lucille. "Sarah Baartman, at rest at last." SouthAfrica.info. South Africa, 14 May 2012. Web. 16 Mar. 2015.

“Europe's 'Human Zoos': Remains of Indigenous Abductees Back Home after 130 Years.” Spiegel Online International. Ergo Direckt, 13 Jan. 2010. Web. 4 Feb. 2015.

Firth, Susan. "Searching for Sara Baartman.” John Hopkins Magazine. The John Hopkins Magazine, 1 June 2009. Web. 28 Dec. 2014.

Holmes, Rachel. African Queen: The Real Life of the Hottentot Venus. New York: Random House, 2007. Print.

Kallipoliti, Lydia. "Evolution of the Zoo: An Overview of Significant Zoological Developments Spanning from Biblical times through to Contemporary Proposals." Wordpress. Terra Incognita, 6 July 2014. PDF. 28 Jan. 2015.

“The Human Zoo: Science's Dirty Secret.” Race: Science's Last Taboo. Channel Four Television Corporation, 1 Jan. 2009. PDF. 27 Dec. 2015.

\section{LIST OF ILLUSTRATIONS}

Bailey, Brett. Civilizing the Natives: Herero prisoners cleaning Herero skulls for European museums, 2014. Digital File. Copyright Brett Bailey.

Bailey, Brett. A Place in the Sun: quarters of an officer of the German Colonial Forces, Windhoek 1906, 2014. Digital File. Copyright Brett Bailey.

Gely, Pascal. Brett Bailey with a performer from Exhibit B, 2014. Digital File. Copyright Pascal Gely.

Unknown. Portrait of Saartjie Baartman, naked, 1810. Digital File. Copyright British Museum. 